
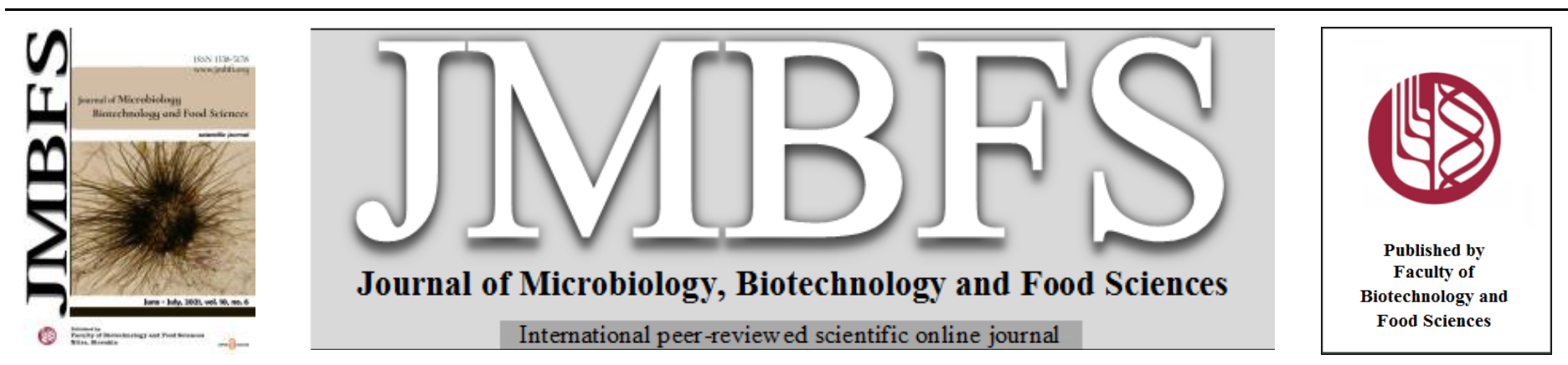

\title{
THE EFFECT OF NATURAL ZEOLITE DIETARY SUPPLEMENTATION ON THE EGG QUALITY OF JAPANESE QUAILS (Coturnix japonica) DURING THE LAYING PERIOD
}

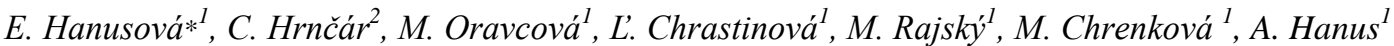 \\ Address(es): RNDr. Emília Hanusová, PhD., \\ ${ }^{1}$ National Agricultural and Food Centre - Research Institute for Animal Production Nitra, Hlohovecká 2, 95141 Lužianky, Slovakia. \\ ${ }^{2}$ Slovak University of Agriculture in Nitra, Faculty of Agrobiology and Food Resources, Tr. A. Hlinku 2, 94976 Nitra, Slovakia.
}

*Corresponding author: emilia.hanusova@nppc.sk

https://doi.org/10.15414/jmbfs.4631

\section{ARTICLE INFO}

Received 30. 3. 2021

Revised 7. 4. 2021

Accepted 16. 4. 2021

Published 1. 6. 2021

Regular article

OPEN $\partial_{\text {ACCESS }}$

\begin{abstract}
The effect of supplementing natural zeolite (NZ) on the laying characteristics and on the internal and external egg quality during laying period of Japanese quails was studied. The laying and average eggs per female were lower in control (C) and the Z1 experimental groups ( $1 \% \mathrm{NZ}$ ) compare with the Z2 experimental group ( $2 \% \mathrm{NZ}$ ). The significant effect of the NZ addition in comparison with the C was found in the eggshell weight and yolk index. The eggshell weight of $C(1.10 \pm 0.01 \mathrm{~g})$ was significantly lower than $Z 1(1.18 \pm 0.01 \mathrm{~g})$. The quails of $\mathrm{Z} 2$ had significantly lower egg weight than $\mathrm{Z} 1$. The average egg weight was significantly affected by diet $(\mathrm{P} \leq 0.05)$ and also by age of quails $(\mathrm{P} \leq 0.001)$. At the beginning of the laying, the weight of the eggs (age 1$)$ was significantly lower $(12.07 \pm 0.12 \mathrm{~g}$ at the beginning, $12.38 \pm 0.12 \mathrm{~g}$ in the middle and $13.38 \pm 0.12 \mathrm{~g}$ in the end) $(\mathrm{P} \leq 0.001)$. The albumen weight and Haugh unit were significantly influenced by the age of the females. The albumen weight increased with female age (from 6.88 to $8.10 \pm 0.09 \mathrm{~g}$ ). The $\mathrm{HU}$ was significantly lower $(89.52 \pm 0.30)$ at the age 1 than in age $2(90.50 \pm 0.30)$ and age $3(90.57 \pm 0.30)(\mathrm{P} \leq 0.05)$. The yolk index was significantly affected by both diet and age of animals. The significant difference was between $\mathrm{C}$ and $\mathrm{Z} 1(\mathrm{P} \leq 0.05)$. The highest yolk index was found in youngest female $(\mathrm{P} \leq 0.01)$. The egg quality was mainly affected by age of females. Diet affected investigated traits to a smaller extent.
\end{abstract}

Keywords: Japanese quail, natural zeolite, egg, egg quality, laying

\section{INTRODUCTION}

Food quality has been a long-debated issue. Current trends in food production are shifting from a quantitative to a qualitative position, which is related to new knowledge about the rational nutrition of the population and thus to the growing interest of the population in quality food. More and more people are realizing that nutrition can directly affect their health. In connection with this, eggs and meat of Japanese quail have become sought-after culinary items. Proof of this is the expansion of Japanese quail breeding in various countries around the world. In addition to the genetic basis, the quality of products is mainly influenced by nutrition. Recently, commercially produced feed has often been used for animal nutrition, the quality of which does not always correspond to the required parameters. The most common problem is the amount of toxins and other undesirable substances in the feed. It is therefore necessary to improve the quality of the feed by adding additives which are able to absorb the harmful substances contained in the feed and ultimately improve the quality of the feed.

Another reason for looking for new alternatives in animal nutrition is the ban on the use of antibiotic growth promoters in animal nutrition.

Despite all zoohygienic measures in breeding, one of the main causes of mass losses and low weight gain in animals is gastrointestinal diseases caused by disturbed intestinal microflora. For poultry farmers, the main goal is to obtain healthy and safe food of animal origin. The greening of animal production leads to the gradual replacement of synthetic feed ingredients by additives of natural origin.

Studies of alternative products that could results in promotion of growth, improvement feed utilization and maintains of gut health are taking place. For this reason natural products are being widely investigated (Haščík $\boldsymbol{e t}$ al., 2017; Čuboň et al., 2020; Pavelková et al., 2020).

Zeolite is a substance of crystal structure, containing cations of alkaline-earth metals. Zeolite is used to modify fermentation processes including buffers, which regulate gut $\mathrm{pH}$ and favour the activity of cellulolytic bacteria, compounds to suppress methane production and bloat-preventing compounds, which prevent the build-up of gas trapped in foam $\left(\mathrm{CO}_{2}, \mathrm{NH}_{3}, \mathrm{H}_{2} \mathrm{~S}, \mathrm{CH}_{4}\right.$ and some nitrogen combinations) in the caecum fluid (Shibaev and Butko, 1986; Shadrin, 1988).
Zeolite-natural and modified, because of their specific structure, are excellent adsorbed and thus can diminish the harmful effect of heavy metals. Clinoptilolites, due to its structural stability under high temperatures and acidity, are the most widely used zeolite in animal studies. The important research data indicated the positive influence of the in-feed inclusion of clinoptilolite on animal health. In human medicine, the experiments in vitro and in vivo have suggested that CPL could be used as an adjuvant in immunodeficiency states and anticancer therapy, antioxidative agent or reducer of the levels of radionuclides (Pavelic $\boldsymbol{e t}$ al. 2001,2003; Zarkovic et al., 2003; Ivkovic et al., 2004).

The effect of using natural zeolite (Clinoptilolite) in poultry diet on their performance are evidences in many works (Basha $\boldsymbol{e t}$ al., 2016; Wawrzyniak $\boldsymbol{e}$ al., 2017; Morsy, 2018; Emam et al., 2019).

Ozturk et al. (1998) by supplementing natural zeolite in various concentration $(20,40,60,80 \mathrm{~g}$ per $1 \mathrm{~kg}$ of diets) observed no significant dietary effects in terms of body weight, feed consumption, feed efficiency ratio, the number of eggs laid per hen, eggshell thickness, mortality or other criteria of egg quality $(\mathrm{P}>0.05)$.

Dietary zeolite improves feed efficiency and egg production in laying hens (Samara, 2003). Moreover, Pavelic and Hadzija (2003) suggested that natural zeolite may have a beneficial effect against aflatoxicosis and other health disorders. Zeolite clinoptilolite is able to adsorb damaging toxins that can potentially reduce the performance of animals (Oğuz and Kurtoğlu, 2000), affect gut morphology, decrease $\mathrm{pH}$, and lower pathogenic bacteria counts, which suggests that intestinal health improvement (Wu et al., 2013). Also, zeolite, being the adsorbents, eliminates a number of toxic substances (heavy metal salts, nitrates, nitrites, mycotoxins, radionuclides, metabolism products) from the organism. The zeolite in diets improves weight gains and feed conversion in broilers (Fethiere et al., 1994) and their physical properties (Tserveni-Gousi $\boldsymbol{e} t$ al., 1997). Addition of natural zeolite to broiler diet led to promote of chicken performance (Nikolakakis et al., 2013) and improve body weight gain and feed conversion ratio (Debeic, 1994). The content of toxins, especially mycotoxins, in animal feed, especially poultry, is important from a health point of view. Thanks to its structure, natural zeolite is able to adsorb mycotoxins from feed and thus contributes to the improvement of animal health (Kermanshahi et al., 2011). 
The important part of egg production as well as their quality is egg number. The egg quality is conditional upon a number of factors such as poultry species, genotype, nutrition, oviposition time, environment and age of laying hens. Johnston and Gous (2007) and Zita et al. $(2009,2012)$ showed that the egg weight increased with hen's age. The egg weight was also affected by the age of the quails. Nazligul et al. (2001) and Orhan et al. (2001) found that egg weight increased with the age of the quail.

Quality of poultry products, especially eggs, is a very important issue for both the producers and consumers. Egg quality has been defined as the characteristics of an egg that affect its acceptability by the consumers. Egg quality is the more important price contributing factor in table and hatching eggs. Therefore, the economic success of a laying flock solely depends on the total number of quality eggs produced (Monira et al., 2003). Egg quality is composed of those characteristics of an egg that affects its acceptability to consumers, it is therefore important that attention is paid to the problems of preservation and marketing of eggs to maintain the quality (Hrnčár et al., 2014).

Gonzales (1995) were analysed the external and internal egg quality of Japanese quails during 6 months of lay. Egg weight, egg length, yolk height and yolk index increased as quail aged. Specific gravity, eggshell plus membrane thickness, egg shape index, albumen height and internal quality unit (IQU) decreased at the en of the experiment. Highest values of eggshell thickness $(0.201 \mathrm{~mm})$ and internal quality unit (69.68) obtained at 17 and 8 weeks of age, respectively, indicated that a better quality of egg was attained at the beginning of lay.

The aim of the study was to investigate the effect of supplementing natura zeolite on the laying characteristics and on the internal and external egg quality during laying period of Japanese quails.

\section{MATERIAL AND METHODS}

\section{Animals and diet}

The experiment was carried out on the Department of Small Farm Animals of the National Agricultural and Food Centre - Research Institute for Animal Production in Nitra. Japanese quails of meat line were included in the experiment. Japanese quails were kept in cage with three females per cage. A cycle of $14 \mathrm{~h}$ of light and $10 \mathrm{~h}$ of dark was used throughout the experiment. They were fed with commercial diets (TEKRO Nitra, Ltd. Slovak Republic). The quails were divided into three groups as follows: the control group received commercial diets without additives (C), the experimental group Z1 were fed a commercial diet enriched with supplement of $1 \%$ natural zeolite and experimental group Z2 were fed a commercial diet enriched with supplement of 2 $\%$ natural zeolite. The animals had the feed and water at libitum. The natural zeolite (ZeoFeed) was supplied by Zeocem Company (Zeocem a.s., Bystré, Slovakia) from the quarry of Nižný Hrabovec, Slovakia. Zeolite used in the experiment had a particle size of $0.2-0.5 \mathrm{~mm}$ and contained more than $80 \%$ of clinoptilolite, as determined by $\mathrm{X}$-ray powder diffraction. Its chemical composition was as follows: $\mathrm{SiO}_{2}-70.98 \%, \mathrm{Al}_{2} \mathrm{O}_{3}-11.72 \%, \mathrm{Fe}_{2} \mathrm{O}_{3}-1.26 \%$, $\mathrm{CaO}-2.89 \%, \mathrm{MgO}-0.53 \%, \mathrm{~K}_{2} \mathrm{O}-3.25 \%, \mathrm{Na}_{2} \mathrm{O}-0.56 \%$ and loss on ignition $7.17 \%$.

Table 1 shows the list of the ingredients and nutrient content of the basal diets formulated to provide the nutrient requirements of quails according to the recommended reference levels. The feed mixture was produced without any antibiotics and coccidiostats.

\section{Egg quality}

The laying was recorded daily from 8 weeks of age until the end of 50 weeks of age (from June (VI) to March (III)). We monitored the effect of the natural zeolite addition on the laying parameters of Japanese quail during the experiment. At the age of 14 (age 1), 23 (age 2) and 45 (age 3) weeks of females, we performed an analysis of eggs. Total 279 eggs were analysed; 31 eggs from each group were analyzed in three different laying periods.

Egg weight was individually determined with $0.001 \mathrm{~g}$ accuracy using a laboratory scale Kern 572-32. Egg length (along the longitudinal axis) and egg width (along the equatorial axis) were measured with a micrometer. Egg shape index was calculated as the ratio of egg width to egg length (\%) by method of Anderson $\boldsymbol{e t}$ al. (2004). After the eggs were broken, eggshells were washed with water and dried in order to clean the remaining albumen. Shell thickness (with membrane) was measured at the sharp poles, blunt poles and equatorial parts of each egg. The albumen weight was calculated as the difference between the egg weight, and the yolk and eggshell weight. Individual Haugh unit score (Haugh, 1937) was calculated using the egg weight and albumen height as follows (Monira $\boldsymbol{e t}$ al., 2003).

Yolk weight with $0.001 \mathrm{~g}$ accuracy was determined using a laboratory scale Kern 572-32 and its percentage proportion was calculated. Yolk colour was determined with La Roche scale (Hoffman-La Roche, Switzerland). Egg length (along the longitudinal axis) and egg width (along the equatorial axis) were measured with a micrometer. Egg shape index was calculated as the ratio of egg width to egg length (\%) by method of Anderson et al. (2004).

Table 1 Composition of basal diet and nutrient content of feed mixture per $\mathrm{kg}$ of diet (KKZ HYD 11)

\begin{tabular}{|c|c|}
\hline Ingredients (\%) & Feed mixture \\
\hline Wheat & 15 \\
\hline Maize & 32 \\
\hline Soybean meal (48 \% CP) & 19.2 \\
\hline Fish meal (71\% CP) & 3 \\
\hline Malt flower & 3 \\
\hline Rapeseed meal & 7 \\
\hline Sunflower meal & 4.5 \\
\hline Monocalcium phosphate & 1 \\
\hline Fodder salt & 0.3 \\
\hline Animal fat & 4 \\
\hline Calcium carbonate & 10 \\
\hline Premix of additives ${ }^{1}$ & 1 \\
\hline \multicolumn{2}{|c|}{ Analysed composition (g.kg-1) } \\
\hline Crude protein & 200 \\
\hline $\mathrm{ME}_{\mathrm{N}}\left(\mathrm{MJ} \cdot \mathrm{kg}^{-1}\right)$ & 11.7 \\
\hline Fibre & 60 \\
\hline Ash & 160 \\
\hline $\mathrm{Ca}$ & 35 \\
\hline $\mathrm{P}$ & 5 \\
\hline $\mathrm{Na}$ & 1.6 \\
\hline Lysine & 11 \\
\hline Methionine + Cysteine & 7.9 \\
\hline Linolic acid & 10 \\
\hline
\end{tabular}

Notes: $\mathrm{CP}=$ crude protein $\mathrm{Ca}=$ calcium; $\mathrm{P}=$ phosphorus; $\mathrm{Na}=$ natrium; $\mathrm{ME}_{\mathrm{N}}=$ nitrogen-corrected metabolizable energy; $\mathrm{MJ}=\quad$ megajoule; ${ }^{1}$ active substances per kilogram of premix: vitamin A $15000 \mathrm{IU}$; vitamin E $20 \mathrm{mg}$; vitamin D3 $2000 \mathrm{IU}$; riboflavin $6 \mathrm{mg}$; cobalamin $20 \mu \mathrm{g}$; Mn $60 \mathrm{mg}$; Zn $40 \mathrm{mg}$; $\mathrm{Fe} 40 \mathrm{mg}$; Cu 6 mg; I $1 \mathrm{mg}$; Se $0.2 \mathrm{mg}$.

\section{Statistical analysis}

Statistical analysis was done using the SAS 9.2 statistical software (2009). The GLM model was applied to study the influence of effects causing variation of individual egg quality parameter and age in Japanese quail. The following model was applied:

$Y_{i j}=\mu+D_{i}+A_{j}+e_{i j}$

where:

$Y_{i j}-$ individual egg quality parameters

$\mu$-intercept

$D_{i}-$ fixed effect of diet $(\mathrm{C}, \mathrm{Z} 1, \mathrm{Z2}) ; \Sigma_{i} E=0$

$A_{j}$ - fixed effect of age $(1,2,3) ; \Sigma_{j} A=0$

$e_{i j}-$ random error; $e_{i j}=N\left(0, I \sigma_{e}{ }^{2}\right)$

$i=1$ to 3

$j=1$ to 3

Differences among means were obtained using Tukey's test for the same number of observations in each class of individual effects.

\section{RESULTS AND DISCUSSION}

The result of laying performance (average laying eggs per hen and laying intensity) of control group (C) and group with addition of different concentration of natural zeolite $(\mathrm{Z1}, \mathrm{Z2})$ in Japanese quails diet are given in table 2. As we can see from the table, the laying and average eggs per female was lower in contro and $\mathrm{Z} 1$ experimental groups compared with the $\mathrm{Z} 2$ experimental group. These parameters were relatively balanced throughout the whole experiment. In agreement with works of Baumgartner and Hetényi (2001) and Hanusová et al. (2013), the laying of Japanese quails was the most intensive until 20 weeks of age. The laying gradually decreased in $\mathrm{C}$ and $\mathrm{Z} 1$ decreases with increasing age. 
Table 2 Laying characteristics of Japanese quail

\begin{tabular}{l|c|c|c|c|c|c}
\hline Month & \multicolumn{2}{|c|}{ Group C } & \multicolumn{2}{c|}{ Group Z1 } & \multicolumn{2}{c}{ Group Z2 } \\
\hline & $\begin{array}{c}\text { Average laying } \\
\text { (piece/hen) }\end{array}$ & $\begin{array}{c}\text { Laying } \\
\text { intensity (\%) }\end{array}$ & $\begin{array}{c}\text { Average laying } \\
\text { (piece/hen) }\end{array}$ & $\begin{array}{c}\text { Laying } \\
\text { intensity (\%) }\end{array}$ & $\begin{array}{c}\text { Average laying } \\
\text { (piece/hen) }\end{array}$ & $\begin{array}{c}\text { Laying } \\
\text { intensity (\%) }\end{array}$ \\
\hline VI & 16.38 & 81.92 & 15.67 & 78.33 & 15.00 & 75.00 \\
VII & 24.98 & 77.67 & 23.00 & 74.19 & 26.10 & 84.19 \\
VIII & 20.31 & 65.51 & 21.09 & 68.04 & 22.00 & 70.97 \\
IX & 19.92 & 66.39 & 16.70 & 55.67 & 25.50 & 85.00 \\
X & 21.42 & 69.09 & 16.33 & 52.69 & 25.50 & 82.26 \\
XI & 14.58 & 48.61 & 12.78 & 42.59 & 23.14 & 77.14 \\
XII & 10.00 & 32.26 & 8.22 & 26.52 & 21.67 & 69.89 \\
I & 8.09 & 26.10 & 9.00 & 29.03 & 26.67 & 86.02 \\
II & 8.60 & 29.66 & 8.44 & 29.12 & 19.17 & 66.09 \\
III & 14.20 & 45.81 & 10.50 & 33.87 & 27.40 & 88.39 \\
Together & $\mathbf{1 5 7 . 3 3}$ & $\mathbf{5 3 . 3 3}$ & $\mathbf{1 5 7 . 4 4}$ & $\mathbf{5 3 . 3 7}$ & $\mathbf{2 5 3 . 2 9}$ & $\mathbf{8 5 . 8 6}$ \\
(295 days) & $\mathbf{5 3 . 2 5}$ &
\end{tabular}

Least squares means and standards errors for external and internal egg quality are given in table 3 . The table shows that the eggs quality is more influenced by age than by the supplementing natural zeolite. The significant effect of the natural zeolite addition in comparison with the control group was found in the eggshell weight and the yolk index. The weight of eggshell of the control group $(1.10 \pm 0.01 \mathrm{~g})$ was significantly lower than the eggshell weight of experimental group Z1 $(1.18 \pm 0.01 \mathrm{~g})(\mathrm{P} \leq 0.05)$. We found just a few significantly differences in some egg quality traits between experimental groups $\mathrm{Z} 1$ and $\mathrm{Z} 2$. It follows that the natural zeolite concentration may have affected some indicators of egg quality (egg weight, eggshell weight, albumen weight).

Tables 3 Least squares means and standards errors for egg quality

\begin{tabular}{|c|c|c|c|c|c|c|c|c|}
\hline \multirow{2}{*}{ Effect } & \multicolumn{4}{|c|}{ NATURAL ZEOLITE } & \multicolumn{4}{|c|}{ AGE } \\
\hline & Control & $\mathrm{Z1}$ & $\mathrm{Z} 2$ & & 1 & 2 & 3 & \\
\hline Trait & & $\mu$ & & $S_{\mu}$ & & $\mu$ & & $S_{\mu}$ \\
\hline \multirow{2}{*}{ Egg weight (g) } & 12.56 & 12.92 & 12.34 & 0.12 & 12.07 & 12.38 & 13.38 & 0.12 \\
\hline & \multicolumn{4}{|c|}{$\mathrm{Z} 1: \mathrm{Z2}^{++}$} & \multicolumn{4}{|c|}{$1: 3^{+++} ; 2: 3^{+++}$} \\
\hline Egg length (mm) & 34.49 & 34.75 & 34.31 & 0.17 & 34.20 & 34.60 & 34.75 & 0.17 \\
\hline \multirow{2}{*}{ Egg width (mm) } & 26.02 & 26.08 & 26.01 & 0.09 & 25.59 & 26.10 & 26.42 & 0.09 \\
\hline & & & & & \multicolumn{4}{|c|}{$1: 2^{+++} ; 1: 3^{+++} ; 2: 3^{+}$} \\
\hline \multirow{2}{*}{ Egg shape index } & 1.33 & 1.33 & 1.32 & 0.01 & 1.34 & 1.33 & 1.32 & 0.01 \\
\hline & & & & & \multicolumn{4}{|c|}{$1: 3^{+}$} \\
\hline \multirow{2}{*}{ Egg shape index (\%) } & 75.54 & 75.09 & 76.02 & 0.36 & 74.94 & 75.54 & 76.17 & 0.36 \\
\hline & & & & & \multicolumn{4}{|c|}{$1: 3^{+}$} \\
\hline \multirow{2}{*}{ Eggshell weight (g) } & 1.10 & 1.17 & 1.08 & 0.01 & 1.08 & 1.11 & 1.17 & 0.01 \\
\hline & \multicolumn{4}{|c|}{$\mathrm{C}: \mathrm{Z1}^{++} ; \mathrm{Z} 1: \mathrm{Z2}^{+++}$} & \multicolumn{4}{|c|}{$1: 3^{+++} ; 2: 3^{++}$} \\
\hline Eggshell percentage $(\%)$ & 8.82 & 9.09 & 8.75 & 0.10 & 8.92 & 8.98 & 8.75 & 0.10 \\
\hline \multirow{2}{*}{$\begin{array}{l}\text { Eggshell thickness - } \\
\text { blunt }(\mu \mathrm{m})\end{array}$} & 214.71 & 213.75 & 212.22 & 0.95 & 218.11 & 212.63 & 209.94 & 0.95 \\
\hline & & & & & \multicolumn{4}{|c|}{$1: 2,3^{+++}$} \\
\hline \multirow{2}{*}{$\begin{array}{l}\text { Eggshell thickness - } \\
\text { sharp }(\mu \mathrm{m})\end{array}$} & 228.40 & 227.08 & 226.56 & 1.03 & 231.42 & 227.23 & 223.39 & 1.03 \\
\hline & & & & & \multicolumn{4}{|c|}{$1: 2^{++} ; 1: 3^{+++} ; 2: 3^{+}$} \\
\hline \multirow{2}{*}{$\begin{array}{l}\text { Eggshell thickness - } \\
\text { equatorial }(\mu \mathrm{m})\end{array}$} & 220.32 & 219.49 & 218.45 & 0.94 & 224.03 & 218.30 & 215.94 & 0.94 \\
\hline & & & & & & & & \\
\hline Eggshell thickness - & 221.14 & 220.11 & 219.08 & 0.93 & 224.52 & 219.39 & 216.42 & 0.93 \\
\hline average $(\mu \mathrm{m})$ & & & & & & & & \\
\hline Albumen weight $(\mathrm{g})$ & 7.47 & 7.64 & 7.20 & 0.09 & 6.88 & 7.33 & 8.10 & 0.09 \\
\hline Albumen weight (g) & & & & & & $1: 2^{++} ; 1$ & $2: 3^{+++}$ & \\
\hline Albumen percentage & 59.27 & 59.18 & 58.26 & 0.45 & 65.94 & 59.20 & 60.56 & 0.45 \\
\hline$(\%)$ & & & & & & & & \\
\hline & 4.78 & 4.69 & 4.74 & 0.05 & 4.55 & 4.77 & 4.89 & 0.05 \\
\hline Albumen height (mm) & & & & & & $1: 2^{+}$ & $3^{+++}$ & \\
\hline Alhumen width (mm) & $45: 34$ & 45.62 & 45.13 & 0.30 & 44.78 & 42.93 & 48.37 & 0.30 \\
\hline Albumen widin (mm) & & & & & & $1: 2,3$ & $: 3^{+++}$ & \\
\hline Albumen index $(\%)$ & 105.92 & 103.34 & 105.75 & 1.43 & 101.85 & 111.57 & 101.60 & 1.43 \\
\hline Albumen index (\%) & & & & & & $1: 2,3$ & $: 3^{+++}$ & \\
\hline Haugh Jnit & 90.46 & 89.72 & 90.41 & 0.30 & 89.52 & 90.50 & 90.57 & 0.30 \\
\hline Haugh Unit & & & & & & & & \\
\hline Yolk weight (g) & 3.99 & 4.11 & 4.07 & 0.07 & 4.12 & 3.93 & 4.11 & 0.07 \\
\hline Yolk neonto $(O 7)$ & 31.94 & 31.75 & 32.97 & 0.42 & 34.21 & 31.74 & 30.71 & 0.42 \\
\hline Yolk percentage $(\%)$ & & & & & & & & \\
\hline Yolk heirht $(\mathrm{mm})$ & 10.60 & 10.51 & 10.31 & 0.09 & 10.42 & 10.30 & 10.70 & 0.09 \\
\hline Yolk height (mm) & & & & & & & & \\
\hline Yolk width (mm) & 23.78 & 24.22 & 24.00 & 0.14 & 22.78 & 23.92 & 25.29 & 0.14 \\
\hline YolK Width (mm) & & & & & & $1: 2,3$ & $2: 3^{+++}$ & \\
\hline & 44.70 & 43.54 & 43.16 & 0.44 & 45.82 & 43.10 & 42.47 & 0.44 \\
\hline Yolk index (\%) & & & & & & & & \\
\hline Yolk colour ( $\left.{ }^{\circ} \mathrm{HL} \mathrm{R}\right)$ & 6.03 & 6.18 & 6.26 & 0.11 & 5.67 & 4.88 & 7.92 & 0.11 \\
\hline Yolk colour ( HLR) & & & & & & $1: 2,3$ & $2: 3^{+++}$ & \\
\hline
\end{tabular}

Legend: $\mu$ - least squares mean, $s_{\mu^{-}}$standard error, ${ }^{+}-\mathrm{P}<0.05,{ }^{++}-\mathrm{P}<0.01,{ }^{+++}-\mathrm{P}<0.001$ 
The egg weight is among the most important parameters not only for consumers, but for egg producers as well (Genchev, 2012). In our experiment, average egg weight was significantly affected by diet $(\mathrm{P} \leq 0.05)$ and also by age of quails $(\mathrm{P} \leq 0.001)$. The Japanese quails of experimental group $\mathrm{Z} 2$ (adding of $2 \%$ natura zeolite) had significantly lower egg weight than experimental group $\mathrm{Z} 1(\mathrm{P} \leq 0.05)$ At the beginning of the laying, the weight of the eggs (age 1) was significantly lower $(12.07 \pm 0.12 \mathrm{~g}$ at the beginning, $12.38 \pm 0.12 \mathrm{~g}$ in the middle and $13.38 \pm 0.12$ $\mathrm{g}$ in the end of lay) $(\mathrm{P} \leq 0.001)$. Similar results found Hanusová et al. (2021) by hens at 7,8 and 13 months of age. The average egg weight was significantly increased with the age of the laying hens $(P<0.001, P=0.0076)$. Naharjan et al. (1991), Gonzales (1995), Altan et al. (1998), Zita et al. (2012, 2013) found that the egg weight increased with the age of Japanese quails. Peric et al. (2017) found significant effect of hen age $(\mathrm{P}<0.01)$ on egg weight, shell strength, albumen height and Haugh unit (HU). Zita et al. (2012) show that egg weight was affected by the age of the hens and quails (overall means 61.13 and $12.52 \mathrm{~g}$, respectively). Despite frequents fluctuations, as the age of the laying hens and quails increased, the yolk index and yolk proportion increased as well, while the albumen index, eggshell strength and shell thickness decreased. The important indicator of the external quality of eggs is the eggshell. A lot of authors have reported that eggshell weight increases and eggshell thickness decreased with quails' age (Gonzales, 1995; Altan et al., 1998; Nazligu et al., 2001; Orhan et al., 2001; Zita et al., 2013). Similar results found Kermanshahi et al. (2011) in hens. The eggshell weight was significantly increasing with age, the lowest was at the beginning of the laying $(1.08 \pm 0.01 \mathrm{~g})$ and the highest at the end of the laying (1.17 $\pm 0.01 \mathrm{~g})$. Tůmová et al. (2014) found in laying hens that the young hens had significantly lower eggshell weight $(6.76 \pm 0.19 \mathrm{~g})$ than the old one $(7.74 \pm 0.19 \mathrm{~g})$. They followed apart age also effect of strain, temperature and oviposition on the eggshell weight. They confirmed that only age had significant effect on these traits. The most important quality traits of the eggshell are its thickness. We did not find the significant differences in eggshell thicknes between groups. This is in agreement with works of Kralik et al. (2006) and Emam et al. (2019). We found that eggshell thickness decreased with female age in all measurement sites. The average eggshell thickness significantly decreased from $224.52 \pm 0.93 \mu \mathrm{m}$ at the beginning of the laying, to $219.39 \pm 0.93 \mu \mathrm{m}$ in the middle of the laying up to the value of $216.42 \pm 0.93 \mu \mathrm{m}$. These agree with result of Hanusová et al. (2021). The thickness of eggshell was demonstrably thinner in all measured positions of the egg with increasing age of laying hens.

The important internal egg quality traits are mainly the albumen weight, Haugh unit and yolk weight. The internal quality of albumen is assessed according to the content and consistency of the solid albumen bag by the albumen. The albumen index is an indicator of egg freshness (Halaj and Golian, 2011). Haugh unit expresses a more complex quality of albumen in relation to its weight (Halaj and Golian, 2011). As we can see from our experiment the addition of natural zeolite did not affect the albumen quality.

The albumen weight and Haugh unit was significantly influenced by the age of the females. The albumen weight increased with female age (from $6.88 \pm 0.09 \mathrm{~g}$ to $8.10 \pm 0.09 \mathrm{~g})$. The Haugh unit was significantly lower $(89.52 \pm 0.30)$ at the age 1 than in age $2(90.50 \pm 0.30)$ and age $3(90.57 \pm 0.30)(\mathrm{P} \leq 0.05)$.

The weight of the egg yolk was not affected by diet or age. The yolk index was significantly affected by both diet and age of animals. We found significan differences between the control group and the experimental group Z1 ( $\mathrm{P} \leq 0.05)$ At the beginning of the laying, the yolk index was significantly higher than in older age $(\mathrm{P} \leq 0.01)$.

The addition of natural zeolite did not significantly affect the yolk colour However, in our experiment, the age of the females had a significant effect on the yolk colour. With increasing age, the yolk colour was significantly darker (from $5.67 \pm 0.11$ to $7.92 \pm 0.11, \mathrm{P} \leq 0.001)$. In our experiment the colour of yolk was darker as compared with Zita et al. (2012) (4.87 \pm 0.07$)$

In conclusion, we can state that the addition of natural zeolite to the feed ration at a concentration of $1 \%$ or $2 \%$ does not negatively affect the internal and external egg quality. Öztürk et al. (1998) also did not observed significant effect of adding natural zeolite in to diets of hens on their egg quality parameters.

\section{CONCLUSION}

Feeding natural substances to Japanese quails did not negatively influence laying parameters. The addition of $2 \%$ of natural zeolite had positive effect on laying performance of Japanese quails. The submitting of natural zeolite to the feed ration at a concentration of $1 \%$ or $2 \%$ did not negatively influence the internal and external egg quality of Japanese quails. The internal and external egg quality was more affected by age of laying female than by supplementing natural zeolite.

Acknowledgments: The publication was supported by the project No. APVV15-0477.

\section{REFERENCES}

Altan, O., Oguz, I., Akbas, Y. (1998). Effect of selection for high body weight and age of hen on egg characteristics in Japanese quail (Coturnix coturnix japonica). Turk. J. Vet. Anim. Sci., 22, 467-473.
Anderson, K. E., Tharrington, J. B., Cutris, P. A., Jones, F. T. (2004). Shell characteristics of eggs from historic strains of single comb white leghorn chickens and relationship of egg shape to shell strength. International Journal of Poultry Science, 3, 17-19.

Basha H.A., Goma A.A., Taha A.E., Abou Elkhair, R. (2016). Effect of different forms of natural zeolite (clinoptilolite) on productive performance and behavioral patterns of broiler chickens. International Journal of Agriculture Science and Veterinary Medicine, 4(4): 1-11. DOI https://www.researchgate.net/publication/315676631

Baumgartner, J., Hetényi, L. (2001). Prepelica japonská. Vydal Výskumný ústav živočíšnej výroy Nitra vo vydavatl'stve Slovenský chov. Vydanie I.,ISBN $80-$ 88872-16-2, $75 \mathrm{~s}$.

Čubon, J., Haščík, P., Hleba, L., Hollý, R., Jurenková, M., Hlebová, M. (2020). Mäsová úžitkovost' a kvalita mäsa vybraných druhov hrabavej hydiny. Vedecká monografia, Vydavatel' SPU v Nitre, 2020, 1. vydanie, 133 s., ISBN 978-80552-2206-6

Debeic, M. (1994). Influence of Clinoptiloliteson Chicken Growth. Poultry. Abstract, 21, 9-309.

Emam, K.R.S., Toraih, H.M., Hassan, A.M., El-Far, A.A.E., Morsy, A.S. Ahmed, N.A.L.H. (2019). Effect of zeolite dietary supplementation on physiological responses and production of laying hens drinking saline well water in South Sinai. World Veterinary Journal, 9, (2), 109-122, ISSN 2322-4568, http://dx.doi.org/10.36380/scil.2019.wvj15.

Fethiere R, Miles, R.D., Harms, R.H. (1994). The utilization of sodium in sodium zeolite A by broilers. Poultry Science, 73, 118-121. DOI:10.3382/ps.0730118

Genchev, A. (2012). Quality and composition of Japanese quail eggs (Coturnix japonica). Trakia Journal of Sciences. 10, 91-101. ISSN 1313-7050 (print), ISSN 1313-3551 (online)

González, M. (1995). Influence of age on physical traits of Japanese quail (Coturnix coturnix japonica) eggs. Annales de zootechnie, INRA/EDP Sciences, 44 (3), 307-312. hal-00889186

Halaj, M., Golian, J.: Vajce, biologické, technické a potravinárske využitie. Vydavatel'stvo Garmond Nitra, 2011, 224 s. ISBN978-80-89148-70-7.

Hanusová, E., Baumgartner, J., Hetényi, L., Hanus, A. (2013). Prepelica japonská. Vydalo Centrum výskumu živočíšnej výroby Nitra, v edícii publikácie CVŽV Nitra, ISBN 978-80-89418-30-5, 100 pp.

Hanusová, E., Hanus, A., Hrnčár, C. (2021). Eggs quality of Oravka breed hens depending on hen's age. Acta fytotechn zootechn, 24, 2021(Monothematic Issue: Problems and Risks in Animal Production): 11-14 https://doi.org/10.15414/afz.2021.24.mi-prap.11-14

Haugh, R. (1937). The Haugh unit for measuring egg quality. U.S. egg \& poultry magazine, 43, 552-555, 573.

Haščí, P., Pavelková, A., Bobko, M., Trembecká, L., Elimam, I. O. E., Capcarová, M. (2017). The effect of bee pollen in chicken diet. World's Poultry Science Journal, 73(3), 643-650. https://doi.org/10.1017/S0043933917000435

Hrnčár, C., Hanusová, E., Hanus, A., Bujko, J. (2014). Effect of genotype on egg quality characteristics of Japanese quail (Coturnix japonica). Slovak J. Anim. Sci., 47, (1), 6-11, ISSN 1337-9984.

Ivkovic, S., Deutsch, U., Silberbach, A., Walraph, E., Mannel, M. (2004). Dietary supplementation with the tribomechanically activated zeolite clinoptilolite in immunodeficiency. Effects on the immune system. Adv Ther 21: 135-147, https://doi.org/10.1007/BF02850340.

Johnston, S.A., Gous, R.M. (2007). Modelling the changes in the proportions of the egg components during a laying cycle. British Poultry Science, 48, (6), 347 353

Kermanshahi, H., Jani, E.H.A., Hashemipour, H., Pilevar, M. (2011). Efficacy of natural zeolite and pigments on yolk color and performance of laying hens. African Journal of Biotechnology. 10,(16), 3237-3242. DOI 10.5897/AJB10.1713, ISSN 1684-5315.

Kralik, G., Šperanda, M., Gajčevic, Z. (2006). Effect of Nanofeed® preparation on egg quality and biochemical indicators in laying hens serum. http://www.cabi.org-animalscience, WPSA-Italy

Monira, K. N., Salahuddin, M., Miah, G. (2003). Effect of breed and holding period on egg quality characteristics of chicken. International Journal of Poultry Science, 2, 261-263.

Morsy, A.S. (2018). Effect of zeolite (Clinoptilolite) as a salinity stress alleviator on semen quality and hemato- biochemical parameters of Montazah cocks under South Sinai conditions. Research Journal of Animal and Veterinary Sciences, 10,(2), 9-17

Nagarajan, S., Narahari, D., Jayaprasad, I. A., Thyagarajan, D. 1991. Influence of stocking density and layer age on production traits and egg quality in Japanese quail. Brit.Poultry Sci., 32, 243-248

Nazligul, A., Turkyilmaz, K., Bardakcioglu, H.E. (2001). A study on some production traits and egg quality characteristics of Japanese quail. Turkish Journal of Veterinary and Animal Sciences, 25,(6),1007-1013.

Nikolakakis, I., Dotas, V., Kargopoulos, A., Hatzizisis, L., Dotas, D., Ampas, Z (2013). Effect of natural zeolite (clinoptilolite) on the performance and litter quality of broiler chickens. Turkish Journal of Veterinary and Animal Sciences, 37, 682-686. Available at:http://www.journals.tubitak.gov.tr/veterinary/ 
Ođuz, H. and Kurtođlu, V. (2000). Effects of clinoptilolite on performance of broiler chickens during experimental aflotoxicocis. British Poultry Science, 41, 512-517. DOI: $10.1080 / 713654953$.

Orhan, H., Erensayin, C., Aktan, S. (2001). Determining egg quality characteristics of Japanese quails (Coturnix coturnix japonica) at different ages. Hayvansal Üretim, 42, (1), 44-49.

Öztürk, E., Erener, G., Sarica, M. (1998). Tr.J. of Agriculture and Forestry, 22, 623-628.

Pavelic K and Hadzija M (2003). Medical applications of zeolites. In: Auerbach SM Carrado KA Dutta PK (eds.) Handbook of Zeolite Science and Technology, Marcel Dekker Inc., New York-Basel, 1143-1174.

Pavelic, K, Hadzija, M., Bederica, L., Pavelic, J., Dikic, I.,Katic, M., Kralj. M., Bosnar, M.H., Kapitanovic, S., Poljak-Blazi, M., Krizanac, S., Stojkovic, R. Jurin, M., Subotic, B., Colic, M.(2001). Natural zeolite clinoptilolite new adjuvant in anticancer therapy. J Mol Med 78, 708-720, https://doi.org/10.1007/s001090000176.

Pavelic, K, Hadzija, M. (2003). Medical applications of zeolites. Auerbach SM, Carrado KA, Dutta PK (eds.) Handbook of

Zeolite Science and Technology, Marcel Dekker Inc, New York - Basel, 11431174 https://doi.org/10.1201/9780203911167.ch24

Pavelková, A., Haščík, P., Capcarová, M., Kalafová, A., Hanusová, E., Tkáčová J., Bobko, M., Čuboň, J., Čech, M., Kačániová, M. (2020). Meat performance of Japanese Quails after the application of Bee bread powder. Potravinarstvo Slovak Journal of Food Sciences, vol. 14, 2020, p. 735-743, ISSN 13370960(online) https://doi.org/10.5219/1330 s://dx.doi.org/10

Perić, L., Đukić Stojčić, M., Bjedov, S. (2017). The Effect of Storage and Age of Hens on the Quality of Table Eggs. Advanced Research in Life Sciences, 1(1), 64-67, DOI: 10.1515/arls-2017-0011.

Samara, M. (2003). Effect of feeding natural zeolite on performance of laying hens drinking saline water. An-Najah University Journal Research, (Master Science, Thesis), 17(2): 184-189. Available at: http://hdl.handle.net/20.500.11888/2055

SAS Institute Inc. 2009. SAS/STAT® 9.2 User's Guide, Second Edition, Cary, NC USA

Shadrin, A. M. (1988). Syberian zeolite in rations of animals and birds. In: "Teoreticheskie i prikladnye problemy vnedrenia prirodnych zeolitov v narodnom choziaystve RSFSR" Kemerovo, 68-70.

Shibaev, N. V., Butko, M. P. (1986). Influence of zeolite on production, veterinary-sanitary indices and biological value of young cattle meat. In: $T e z$ Dokl. konferentsii, "Dobycha, pererabotka i primenenie zeolitov", Tbilisi, 149149.

Tserveni-Gousi, A.S., Yannakopoulos, A.L., Katsaounis, N.K., Filippidis, A., Kassoli-Fournaraki, A. (1997) Some interior egg characteristics as influenced by addition of Greek clinoptilolitic rock material in the hen diet. Archive of fur Geflugelkunde, 61: 291-296. Available at: https://www.european-poultryscience.com/artikel.dll/1997-61-291-296_NTAwMzcxMg.

Tukmechi, A., Rahmati Andarani, H.R., Manaffar, R., Sheikhzadeh, N. (2011). Dietary administration of beta-mercapto-ethanol treated Saccharomyces cerevisiae enhanced the growth, innate immune response and disease resistance of the Rainbow trout, Oncorhynchus mykiss. Fish and Shellfish Immunology, 30, 923-928. DOI:10.1016/j.fsi.2011.01.016

Tůmová, E., Gous, R.M. , Tyler, N. (2014). Effect of hen age, environmental temperature, and oviposition time on egg shell quality and egg shell and serum mineral contents in laying and broiler breeder hens. Czech J. Anim. Sci., 59, (9), 435-443.

Wawrzyniak, A., Kapica, M., Stępień-Pyśniak, D., , Szewerniak, R., Olejarska, A., Jarosz, L. (2017). Effect of feeding transcarpathian zeolite on gastrointestinal morphology and function in broiler chickens. Brazilian Journal of Poultry Science, 19(4): 737-746. DOI:http://dx.doi.org/10.1590/1806-9061-2016-0360

Wu, Q.J., Wang, L.C., Zhou,,Y.M., Zhang, J.F., Wang, T. (2013). Effects of clinoptilolite and modified clinoptilolite on the growth performance, intestinal microflora, and gut parameters of broilers. Poultry Science, 92, 684-692. DOI:10.3382/ps.2012-02308

Zarkovic, N., Zarkovic, K., Kralj, M., Borovic, S., Sabalovic, S., Poljak-Blazi, M., Cipak, A., Pavelic, K. (2003). Anticancer and antioxidant effects of micronized zeolite clinoptilolite. Anticancer Res., 23, 1589-1595.

Zita, L., Ledvinka, Z., Klesalová, L. (2013). The effect of the age of Japanese quails on certain egg quality traits and their relationship. Veterinarski Archiv 83, 2, 223-232.

Zita, L., Ledvinka, Z., Tůmova, E., Klesalova, L. (2012). Technological quality of eggs in relation to the age of laying hens and Japanese quails. R. Bras. Zootec., 41, (9), 2079-2084.

Zita, L., Tůmová, E., Štolc, L. (2009). Effects of genotype, age and their interaction on egg quality in brown-egg laying hens. Acta Veterinaria Brno, 78 (1), 85-91. 